\title{
XXIIIrd INTERNATIONAL CONFERENCE OF THE RED CROSS
}

We give below the draft Programme and the provisional Agenda for the XXIIIrd International Conference of the Red Cross (Bucharest, 4 to 21 October 1977), as adopted by the Standing Commission at its latest meeting. ${ }^{1}$

\section{DRAFT PROGRAMME}

\section{Tuesday 4 October}

9.30 a.m. Standing Commission of the International Red Cross Relief Advisory Committee Development Programme Advisory Committee

3.00 p.m. Standing Commission of the International Red Cross Relief Advisory Committee

Development Programme Advisory Committee

\section{Wednesday 5 October}

9.30 a.m. Committee of the President and Vice-Presidents Development Programme Advisory Committee Relief Advisory Committee

3.00 p.m. Committee of the President and Vice-Presidents Development Programme Advisory Committee Relief Advisory Committee

\section{Thursday 6 October}

9.30 a.m. Peace Commission

Standing Finance Commission of the League Relief Advisory Committee

Development Programme Advisory Committee

\footnotetext{
${ }^{1}$ See International Review, December 1976.
} 
3.00 p.m. Peace Commission

Standing Finance Commission of the League

Relief Advisory Committee

Development Programme Advisory Committee

Commission for the Financing of the International

Committee of the Red Cross

Friday 7 October

9.30 a.m. Meeting of Chairman and Vice-Chairmen of Advisory Committees

Standing Finance Commission of the League

Constitution Commission

3.00 p.m. Opening meeting and 1st meeting of the XXXIVth Session of the Board of Governors of the League

5.30 p.m. Constitution Commission

Saturday 8 October

9.30 a.m. Second meeting of the Board of Governors

3.00 p.m. Third meeting of the Board of Governors

Sunday 9 October

No meetings

Monday 10 October

9.30 a.m. Fourth meeting of the Board of Governors

3.00 p.m. Fifth meeting of the Boalrd of Governors

Tuesday 11 October

9.30 a.m. Sixth meeting of the Board of Governors

$3.0 \mathrm{C}$ p.m. Seventh meeting of the Board of Governors

Wednesday 12 October

9.30 a.m. Council of Delegates

3.00 p.m. Council of Delegates

5.00 p.m. Standing Commission of the International Red Cross

Thursday 13 October

9.30 a.m. Council of Delegates ( 3 working groups)

3.00 p.m. Council of Delegates ( 3 working groups)

Friday 14 October

9.30 a.m. Council of Delegates (3 working groups)

3.00 p.m. Council of Delegates ( 3 working groups) 
IN THE RED CROSS WORLD

Saturday 15 October

9.30 a.m. Council of Delegates (3 working groups)

Noon: Opening of the Conference

4.00 p.m. Plenary meeting

Sunday 16 October

No meeting

Monday 17 October

9.30 a.m. Community Services and Development Commission

Protection and Assistance Commission

General and Organizational Commission

3.00 p.m. Community Services and Development Commission

Protection and Assistance Commission

General and Organizational Commission

Tuesday 18 October

9.30 a.m. Community Services and Development Commission Protection and Assistance Commission

General and Organizational Commission

3.00 p.m. Community Services and Development Commission

Protection and Assistance Commission

General and Organizational Commission

\section{Wednesday 19 October}

9.30 a.m. Community Services and Development Commission

Protection and Assistance Commission

General and Organizational Commission

Afternoon: No meetings (Preparation of Commissions' reports)

\section{Thursday 20 October}

Morning: No meetings (Preparation of Commissions' reports)

3.00 p.m. Plenary meeting

\section{Friday 21 October}

9.30 a.m. Plenary meeting

3.00 p.m. Plenary meeting

End of the day: Standing Commission of the International Red Cross 


\section{PROVISIONAL AGENDA}

\section{Council of Delegates}

1. Election of the Chairman, Vice-Chairmen and Secretaries of the Council of Delegates.

2. Proposals to be made for the election of the Chairman, Vice-Chairmen Secretary General and Assistant Secretaries General of the Conference.

3. Approval of the draft Agenda of the Conference drawn up by the Standing Commission.

4. Follow-up to resolutions of the Council of Delegates in 1973 and 1975.

5. Funds and medals:

(a) award of the Henry Dunant Medal;

(b) report on the income of the Augusta Fund and the awards of the Florence Nightingale Medal;

(c) report of the Joint Commission of the Empress Shoken Fund;

(d) report of the Commission for the Financing of the ICRC;

(e) report of the Council of the Foundation for the ICRC.

6. Report on the activities of the Henry Dunant Institute.

7. Report on the Reappraisal of the Role of the Red Cross.

Constitution of three working parties to prepare the discussion of the Report by the International Conference:

Group A: subjects to be dealt with by Commission I:

Protection and Assistance;

Group B: subjects to be dealt with by Commission II:

General and Organizational;

Group C: subjects to be dealt with by Commission III:

Community Services and Development. 


\section{Plenary Meetings}

1. Report of the Council of Delegates.

2. Election of the Chairman, Vice-Chairmen, Secretary General and Assistant Secretaries General.

3. Appointment of Conference Commissions:

Commission I: Protection and Assistance;

Commission II: General and Organizational;

Commission III: Community Services and Development;

Resolutions Drafting Committee.

4. Opening of the procedure for the election of members of the Standing Commission.

5. Formal reading of the Fundamental Principles of the Red Cross.

6. Reports of the Commissions:

(a) Commission I;

(b) Commission II;

(c) Commission III;

(d) Fundamental Role of the Red Cross.

7. Election of members of the Standing Commission.

8. Place and date of the twenty-fourth International Conference of the Red Cross.

\section{Meetings of Commissions}

Commission I: Protection and Assistance

I. Election of the Chairman, Vice-Chairmen, Rapporteur and Drafting Committee.

II. Report on the action taken on the resolutions of the XXIInd International Conference.

III. Results of the Diplomatic Conference on the Reaffirmation and Development of International Humanitarian Law applicable in Armed Conflicts.

IV. Reappraisal of the Role of the Red Cross.

1. Fundamental role; 
2. Assistance in the event of natural disasters:

(a) proposals of a general nature,

(b) collaboration with other organizations,

(c) new ventures;

3. Protection and assistance in the event of armed conflict:

(a) proposals of a general nature,

(b) development of international humanitarian law,

(c) dissemination of international humanitarian law and of Red Cross principles,

(d) protection and assistance in cases covered by international humanitarian law,

(e) protection and assistance in situations not covered by international humanitarian law;

4. Planning for action in natural disasters and in armed conflicts.

V. Miscellaneous.

\section{Commission II: General and Organizational}

I. Election of the Chairman, Vice-Chairmen, Rapporteur and Drafting Committee.

II. Report on the action taken on the resolutions of the XXIInd Conference.

III. Reports on the activities of the International Committee of the Red Cross, of the League of Red Cross Societies, and of the National Red Cross, Red Crescent and Red Lion and Sun Societies.

IV. Reappraisal of the Role of the Red Cross:

1. Fundamental role;

2. Fundamental principles;

3. Emblems;

4. The Red Cross and Peace;

5. International Conferences of the Red Cross and the Council of Delegates;

6. Standing Commission of the International Red Cross; 
IN THE RED CROSS WORLD

7. National Societies;

8. International Committee of the Red Cross;

9. League of Red Cross Societies.

V. Miscellaneous.

Commission III : Community Services and Development

I. Election of the Chairman, Vice-Chairmen, Rapporteur and Drafting Committee.

II. Report on the action taken on the resolutions of the XXIInd International Conference.

III. Reappraisal of the Role of the Red Cross:

1. Fundamental role;

2. Health and social welfare;

3. Development;

4. Youth;

5. Information.

IV. Environment.

V. Miscellaneous. 